\title{
KEBIJAKAN FORMULASI ASAS SIFAT MELAWAN HUKUM MATERIEL DALAM HUKUM PIDANA INDONESIA
}

\author{
Syarifa Yana \\ Dosen Program Studi Ilmu Hukum Universitas Riau Kepulauan
}

Di dalam KUHP dianut asas legalitas yang dirumuskan dalam Pasal 1 ayat (1) yang hanya mengakui sumber hukum tertulis, yang sekaligus menegaskan bahwa KUHP juga menganut asas sifat melawan hukum yang formal. Namun demikian, secara teoritis dan menurut yurisprudensi serta menurut rasa keadilan dalam masyarakat, diakui adanya sumber hukum tidak tertulis yang sekaligus mengakui asas sifat melawan hukum materiel.

Hukum pidana mengatur perbuatan yang dilarang dan diancam dengan pidana yang dinamakan perbuatan pidana/ tindak pidana. Dalam sistem KUHP perbuatan tersebut dibagi atas dua yaitu kejahatan (rechtsdelict), dan pelanggaran (wetsdelict). ${ }^{1}$ Perbuatan-perbuatan pidana tersebut menurut wujud dan sifatnya bertentangan dengan tata atau ketertiban yang dikehendaki oleh hukum. Tegasnya perbuatan tersebut merugikan masyarakat, dalam arti bertentangan atau menghambat terlaksananya tata dalam pergaulan masyarakat yang baik dan adil. Untuk itu perbuatan-perbuatan tersebut dilarang keras untuk dilakukan.

Tentang penentuan perbuatan mana yang dipandang sebagai perbuatan pidana, dianut asas yang dinamakan asas legalitas (principle of legality), yaitu asas yang menentukan bahwa tidak ada perbuatan yang dilarang dan diancam dengan pidana jika tidak ditentukan terlebih dahulu dalam perundang-undangan. Rumusan asas legalitas tersebut diformulasikan dalam Pasal 1 ayat (1) KUHP yang merupakan landasan yuridis.

Asas legalitas dikenal juga sebagai asas sumber hukum. Sebagai asas sumber hukum, perumusan asas legalitas dalam KUHP hanya mengakui eksistensi berlakunya sumber hukum tertulis sebagai dasar untuk menyatakan suatu perbuatan (feit) sebagai perbuatan yang dapat dipidana (strafbaarfeit). Artinya bahwa yang diakui hanya asas legalitas formal, dimana hukum

\footnotetext{
${ }^{1}$ Moeljatno, Asas-Asas Hukum Pidana (Edisi revisi), Penerbit Rineka Cipta, Jakarta, 2008, Hal. 78.
} 
diartikan sebagai undang-undang semata. Alur tersebut juga menegaskan bahwa yang dianut dalam KUHP adalah asas sifat melawan hukum yang formal.

Namun demikian, secara teoritis dan menurut yurisprudensi serta menurut rasa keadilan, diakui adanya asas "sifat melawan hukum materiel" atau dikenal juga dengan asas "tiada tindak pidana dan pemidanaan tanpa sifat melawan hukum secara materiel". ${ }^{2}$ Untuk itu setiap perbuatan pidana/ tindak pidana dianggap selalu bertentangan dengan hukum. Artinya, walaupun dalam perumusan delik tidak dirumuskan secara tegas adanya unsur melawan hukum, namun delik tersebut harus dianggap bersifat melawan hukum. Asas ini sebenarnya juga tersimpul di dalam aturan khusus KUHP, walaupun hanya secara implisit, yaitu dalam rumusan delik yang menyebutkan sifat melawan hukum. Apabila unsur melawan hukum tersebut tidak ada/ tidak terbukti, maka si pelaku tidak dapat dipidana. ${ }^{3}$ Hal ini menunjukkan bahwa di dalam KUHP terdapat asas "tiada pertanggungjawaban pidana tanpa sifat melawan hukum" (no liability without unlawfulness).

Walaupun asas/ ajaran sifat melawan hukum materiel terdapat secara implisit di dalam aturan khusus KUHP, akan tetapi dikhawatirkan asas sifat melawan hukum materiel ini akan tetap dilupakan, dinisbikan bahkan diharamkan dalam pemberlakuan hukum pidana.

Dalam tataran praktik di masyarakat juga menunjukkan bahwa banyak perbuatan yang dianggap tercela karena tidak sesuai dengan rasa keadilan atau norma-norma kehidupan sosial (nilai kepatutan) dalam masyarakat akan tetapi perbuatan tersebut tidak dirumuskan dalam suatu bentuk peraturan perundangundangan. Bahkan sebaliknya ada suatu perbuatan yang dianggap masyarakat bukan merupakan tindak pidana akan tetapi disebut sebagai tindak pidana dalam suatu peraturan perundang-undangan.

Dalam masyarakat juga dikenal sumber hukum lain selain sumber hukum dalam formatnya sebagai undang-undang yaitu hukum kebiasaan rakyat yang tidak tertulis. ${ }^{3}$ Hukum kebiasaan tersebut telah dianut jauh sebelum datangnya inovasi kehidupan bernegara. Standar-

\footnotetext{
${ }^{2}$ Barda Nawawi Arief, Bunga Rampai Kebijakan Hukum Pidana Perkembangan Penyusunan Konsep KUHP Baru, Kencana, Jakarta, 2008, Hal. 80. ${ }^{3}$ Ibid., Hal.80.

${ }^{3}$ Dikenal juga dengan sebutan lawways (istilah yang digunakan Hoebel seorang antropolog), folkways (Summer sang sosiolog), adatrecht (oleh Snouk Hurgronye). Folkways atau lawways adalah adat kebiasaan masyarakat yang selalu beresensi moral. Istilah lain yang dikenal adalah local wisdom, local genius atau living law. Di Indonesia istilah lain yang dikenal untuk penyebutan hukum kebiasaan adalah kearifan lokal. lihat dalam Soetandyo Wignjosoebroto, Hukum Dalam Masyarakat Perkembangan dan Masalah: Sebuah Pengantar Ke Arah Kajian Sosiologi Hukum, Bayumedia Publishing, Malang, 2008, Hal. 66.
} 
standar perilaku masyarakat tampak sebagai pola-pola pengalaman yang diikuti sebagai kebiasaan yang baik, dan apabila dipatuhi akan mendatangkan kemaslahatan dan keselamatan.

Akan tetapi dalam praktiknya dalam usaha memberikan jaminan kepastian hukum melalui usaha mempositifkan berbagai kebijakan nasional ke dalam bentuk undang-undang terdapat banyak perbedaan secara substansi dari apa yang telah banyak dilazimkan dan diadatkan dalam khazanah hukum rakyat. Hal ini menyebabkan hukum positif yang terwujud dalam bentuk undang-undang tersebut tidak menciptakan/ mencerminkan rasa keadilan masyarakat.

\section{Kebijakan Formulasi Asas Sifat Melawan Hukum Materiel Dalam Hukum Pidana Indonesia}

Dalam perumusan KUHP yang saat ini berlaku di Indonesia, tidak pernah disebutkan secara eksplisit tentang istilah/ judul dari "asas-asas hukum pidana". Asas-asas tersebut umumnya hanya dikemukakan dalam pelajaran/ ilmu hukum pidana yang biasanya disimpulkan dari perumusan norma yang terkandung di dalamnya. Misalnya di dalam Bab I Buku I KUHP tentang "batas-batas berlakunya aturan pidana dalam perundangundangan" (Pasal 1 s/d 9) terkandung asas-asas ruang berlakunya hukum pidana menurut waktu (asas legalitas) dan menurut tempat (asas teritorial, asas nasional aktif atau asas personal, asas nasional pasif atau asas perlindungan, dan asas universal). Asas-asas inilah yang pada umumnya dikenal, bahkan yang paling dikenal dan menonjol adalah asas legalitas. Asas-asas tersebut diformulasikan sebagai asas umum dalam aturan umum/ Buku I KUHP.

Namun demikian, di samping asas-asas tersebut, di dalam KUHP sebenarnya juga tersimpul adanya asas-asas lain. Misalnya saja asas sifat melawan hukum materiel, dikenal juga sebagai asas "tiada pidana/ pertanggungjawaban pidana tanpa sifat melawan hukum" (no liability without unlawfulness) atau asas "tidak adanya sifat melawan hukum secara materiel" (asas AVAWafwezigheids van alle materiel wederrechtelijkheid) yang tersimpul secara implisit di dalam aturan khusus $\mathrm{KUHP}^{4}$ yaitu dari adanya pencantuman unsur "melawan hukum" dalam perumusan delik tertentu di dalam aturan khusus KUHP, meskipun tidak dirumuskan secara

\footnotetext{
${ }^{4}$ Barda Nawawi Arief, Bunga Rampai Kebijakan Hukum Pidana Perkembangan Penyusunan Konsep KUHP Baru, Op.Cit.
} 
eksplisit dalam aturan umum KUHP. ${ }^{5}$ Padahal secara teoritis dan yurisprudensi serta menurut rasa keadilan, keberadaan asas tersebut juga diakui.

Senada dengan pernyataan di atas, J. A. W. Lensing juga pernah mengemukakan bahwa di dalam KUHP juga terdapat asas "tidak adanya sifat melawan hukum secara materiel” (asas AVAW-afwezigheids van alle materiel wederrechtelijkheid) sebagai asas untuk menghapuskan (menegatifkan) sifat melawan hukumnya perbuatan (secara formal). Hanya saja asas itu tidak diformulasikan sebagai asas umum (dalam Buku I). ${ }^{6}$ Artinya bahwa meskipun tidak diformulasikan secara eksplisit sebagai asas umum, di dalam KUHP juga terdapat asas sifat melawan hukum materiel yaitu dalam fungsinya yang negatif.

Untuk mengetahui adanya asas sifat melawan hukum materiel dalam KUHP dapat dilihat dari beberapa perumusan tindak pidana/ delik dalam aturan khusus KUHP yang secara eksplisit menyebutkan unsur "melawan hukum", antara lain : a. Pasal 167 ayat (1)

b. Pasal 333 tentang perampasan kemerdekaan

c. Pasal 368 ayat (1) tentang pemerasan

d. Pasal 406 tentang perusakan barang

Dari pasal-pasal di atas dapat diambil suatu pemahaman, bahwa untuk menentukan suatu perbuatan sebagai tindak pidana sangat terkait dengan pembuktian unsur "melawan hukum". Hal ini merupakan konsekuensi dari pencantuman unsur "melawan hukum" dalam rumusan tindak pidana. Dimana beban pembuktian akan jatuh pada jaksa, sebab dengan menuduhkan pasal tertentu mewajibkan jaksa untuk memuat unsur-unsur tindak pidana yang dituduhkan dalam surat dakwaan dan membuktikan dakwaannya. Kemudian pada gilirannya hakim akan menafsirkan arti "melawan hukum" dari fakta yang terungkap di muka sidang pengadilan.

Dalam pembuktian untuk menentukan suatu perbuatan yang melawan hukum dapat langsung dipidana atau tidak, seorang hakim harus terlebih dahulu melihat pada alasan-alasan yang dapat menghapuskan sifat melawan hukumnya suatu perbuatan/ alasan pembenar. Alasan-alasan tersebut dapat berasal dari hukum tertulis maupun hukum yang tidak tertulis (nilai-nilai yang

\footnotetext{
5 Barda Nawawi Arief, Perkembangan Asas Hukum Pidana Indonesia, Penerbit Pustaka Magister, Semarang, 2008, Hal. 8.

${ }^{6}$ Barda Nawawi Arief, Bunga Rampai Kebijakan Hukum Pidana Perkembangan Penyusunan Konsep KUHP Baru, Op.Cit., hal. 80-81.
} 
hidup dan berkembang dalam masyarakat). Oleh karena itu tidak lah selalu si pelaku tindak pidana dapat dihukum, meskipun perbuatannya telah memenuhi rumusan undang-undang.

Selain itu diketahui bahwa dalam kenyataannnya undang-undang selalu terbelakang/ tertinggal dari pertumbuhan dan perkembangan masyarakat. Masyarakat adalah hidup dan selalu bergerak. Kegiatan kehidupan manusia itu sedemikian luasnya, sehingga tidak terhitung lagi jenis dan jumlahnya. Dengan demikian maka tidak mungkin peraturan perundang-undangan mengatur atau mencakup seluruh kegiatan kehidupan manusia, sehingga ada kalanya apa yang tertulis dalam undangundang jika diterapkan akan tidak sesuai lagi, atau bahkan mengusik rasa keadilan dalam masyarakat. Lagi pula doktrin telah dapat menerima kenyataan bahwa perundang-undangan tidak lengkap dan tidak jelas. Tidak ada peraturan perundangundangan yang lengkap selengkap-lengkapnya dan jelas sejelas-jelasnya. Untuk itu diperlukan upaya penggalian hukum/ penemuan hukum dalam penyelesaian suatu tindak pidana.

Dari beberapa ketentuan dalam aturan khusus KUHP yang mencantumkan unsur "melawan hukum" dalam rumusan tindak pidana (Pasal 167 ayat (1), 333, 368 ayat (1), dan 406) di atas jelas memperlihatkan bahwa selain menganut asas sifat melawan hukum formal, KUHP juga menganut asas sifat melawan hukum materiel dalam fungsi yang negatif yaitu dijadikan sebagai alasan untuk meniadakan sifat melawan hukumnya suatu perbuatan, atau sebagai alasan penghapus pidana yaitu sebagai alasan pembenar.

Walaupun ajaran sifat melawan hukum secara materiel terdapat secara implisit di dalam aturan khusus KUHP, akan tetapi dikhawatirkan asas/ ajaran sifat melawan hukum secara materiel ini akan tetap dilupakan, dinisbikan bahkan diharamkan dalam pemberlakuan/ praktek hukum pidana karena tidak ada perumusannya secara eksplisit di dalam KUHP. Untuk itu asas tersebut harus dirumuskan secara eksplisit sebagai asas umum dalam aturan umum KUHP.

\section{B. Penerapan Asas Sifat Melawan Hukum Materiel Dalam Praktik Hukum} Pidana Di Indonesia

Dalam praktik hukum pidana di Indonesia, pada umumnya para ahli hukum sependapat, bahwa asas sifat melawan hukum yang dianut adalah asas sifat melawan hukum materiel, 
sedangkan asas sifat melawan hukum formil sudah tidak dianut. ${ }^{7}$ Asas sifat melawan hukum materiel yang dianut adalah asas sifat melawan hukum materiel baik dalam fungsi yang negatif maupun fungsi yang positif.

Alasan dianutnya sifat melawan hukum materiel dalam praktik hukum pidana Indonesia dikarenakan dalam kehidupan masyarakat banyak ditemukan alasan-alasan yang dapat menghapuskan sifat melawan hukum suatu perbuatan.

Misalnya seorang ayah memukul seorang pemuda yang memperkosa anak gadisnya. Dalam hal ini perbuatan sang ayah sebenarnya bertentangan dengan Pasal 351 KUHP yang mengatur tentang penganiayaan, akan tetapi sifat melawan hukumnya perbuatan sang ayah terhadap pemuda tersebut oleh nilai-nilai yang hidup dalam masyarakat dianggap tidak ada. Masyarakat akan mengatakan bahwa perbuatan sang ayah merupakan perbuatan yang wajar dan patut, berhubung pemuda tersebut telah memperkosa anak gadisnya.

Akan tetapi yang perlu mendapat perhatian adalah sampai seberapa jauh dampak/ akibat pukulan sang ayah tersebut pada sang pemuda itu. Apabila pukulan itu sampai berakibat luka atau luka berat bahkan kematian, maka tidak menutup kemungkinan atau bahkan pasti perbuatan sang ayah tetap dianggap sebagai perbuatan yang bersifat melawan hukum. Artinya masyarakat mungkin tidak lagi menganggap perbuatan tersebut sebagai perbuatan yang wajar atau patut, sehingga karenanya sang ayah dapat dianggap telah melakukan tindak pidana.

Di samping alasan-alasan yang dapat menghapuskan sifat melawan hukum suatu perbutan pidana (sebagai asas sifat melawan hukum materiel dalam fungsi negatif) sebagaimana yang diterangkan dalam ilustrasi di atas, dalam masyarakat juga terdapat perbuatan-perbuatan yang dapat disebut sebagai tindak pidana meskipun tidak ada pengaturannya dalam peraturan perundang-perundang. Hal ini lah yang dikenal dengan perbuatan melawan hukum materiel dalam fungsi positif.

Adanya contoh sehari-hari terhadap penerapan sifat melawan hukum materiel dalam fungsi positif dapat dilihat dalam kehidupan masyarakat. Misalnya "kumpul kebo" di antara pria dan wanita dewasa yang belum terikat perkawinan. Perbuatan tersebut sering ditemukan pada kehidupan masyarakat kota metropolitan dan dianggap sebagai perbuatan yang wajar, akan tetapi bagi masyarakat tertentu (masyarakat adat) yang jauh dari kehidupan terang benderang

\footnotetext{
${ }^{7}$ Sudarto, Hukum Pidana I, Yayasan Sudarto, Fakultas Hukum UNDIP, Semarang, 1990, hal. 80.
} 
metropolitan seperti halnya Jakarta, Surabaya, maupun kota besar lainnya di Indonesia, maka perbuatan itu dipandang sebagai perbuatan tercela.

Perbuatan "kumpul kebo" itu tidak ada padanannya atau ekuivalensinya dengan KUHP, sehingga perbuatan itu formil tidak melawan hukum meskipun perbuatan itu dipandang sangat tercela (materiel melawan hukum), karenanya bagi para pelakunya tidak dapat dikenakan sanksi pidana. Namun berdasarkan hukum adat yang berlaku di Indonesia, perbuatan kumpul kebo adalah suatu perbuatan tercela, maka perbuatan itu dapat dipidana.

Indonesia sebagai negara hukum melalui Pasal 18B ayat (2) Undang-undang Dasar Negara Republik Indonesia Tahun 1945 mengakui secara penuh eksistensi masyarakat hukum adat/ hukum tidak tertulis beserta hak-hak tradisionalnya sepanjang masih hidup. Adapun ketentuan tersebut berbunyi "negara mengakui dan menghormati kesatuan-kesatuan masyarakat hukum adat beserta hak-hak tradisionalnya sepanjang masih hidup dan sesuai dengan perkembangan masyarakat dan prinsip Negara Kesatuan Republik Indonesia yang diatur dalam undangundang”.

Selain itu pengakuan eksistensi hukum adat/ hukum yang hidup/ hukum tidak tertulis sebagai sumber hukum untuk mempidana suatu perbuatan yang melawan hukum dapat dilihat dari Undang-undang Darurat No. 1/ Drt/ 1951 tentang Tindakantindakan Sementara Untuk Menyelenggarakan Kesatuan Susunan, Kekuasaan dan Pengadilan- Pengadilan Sipil, khususnya Pasal 5 ayat (3) sub b. Ketentuan tersebut menyatakan bahwa suatu perbuatan menurut hukum yang hidup harus dianggap perbuatan pidana, akan tetapi tiada bandingnya dalam KUHP, maka dianggap diancam dengan hukuman yang tidak lebih dari 3 (tiga) bulan penjara dan/ atau denda lima ratus rupiah, yaitu sebagai hukuman pengganti bilamana hukuman adat yang dijatuhkan tidak diikuti oleh pihak yang terhukum dan penggantian yang dimaksud dianggap sepadan oleh hakim dengan besar kesalahan terhukum.

Dari bunyi redaksional pasal di atas jelas menunjukkan adanya suatu perbuatan yang dipandang sebagai perbuatan pidana atau materiel perbuatannya adalah perbuatan melawan hukum/ tercela, tetapi perbuatan tersebut tidak ada pengaturannya dalam KUHP atau perbuatannya secara formil tidaklah melawan hukum, wajib bagi hakim untuk menjatuhkan pidana untuk maksimum 3 (tiga) bulan penjara dan/ atau denda lima ratus rupiah. Pelaku tidak begitu saja tidak dapat dipidana dengan alasan legalitas, mengingat eksistensi hukum yang hidup, setidaknya substansi dari tindak pidana menurut masyarakat itu hingga kini masih berlaku di Indonesia. 
Dari adanya contoh perbuatan yang melawan hukum secara materiel menurut masyarakat di atas menunjukkan bahwa adanya pergeseran asas sifat malawan hukum, yaitu dari asas sifat melawan hukum secara formil menjadi asas sifat melawan hukum secara materiel baik dalam fungsinya yang negatif yaitu sebagai alasan yang menghapuskan sifat melawan hukum suatu perbuatan maupun dalam fungsinya yang positif yaitu menyatakan suatu perbuatan sebagai perbuatan/ tindak pidana meskipun tidak ada pengaturannya dalam peraturan perundangundangan.

Keberadaan undang-undang yang dibatasi dengan adanya pengakuan asas legalitas tidak cukup memberikan kepuasan bagi hakim dalam mencari keadilan. Karena itu, dalam putusanputusan hakim sering ditemukan kaidah-kaidah baru yang mengenyampingkan ketentuan peraturan perundang-undangan tersebut. Salah satu bentuknya adalah perlunakan/ penghalusan atau pergeseran/ perluasan dari asas legalitas.

Dalam praktik peradilan, dapat dijumpai beberapa putusan yang mengakui asas sifat melawan hukum baik dalam fungsinya yang negatif maupun yang positif, antara lain Putusan Mahkamah Agung No. 42/ K/ Kr/ 1965 tanggal 8 Januari 1966 dengan terdakwa Machroes Effendi, Putusan Mahkamah Agung No. 30/ K/ Kr/ 1969 tanggal 6 Juni 1970 dengan terdakwa adalah seorang pedagang kelontong, Putusan Mahkamah Agung No 72 K/ Kr/ 1970 tanggal 27 Mei 1972, Putusan Mahkamah Agung No. 195 K/ Kr/ 1978 tanggal 8 Oktober 1979, Putusan Mahkamah Agung No. 93 K/ Kr/ 1976 tanggal 19 Nopember 1977, Putusan Mahkamah Agung No. 275 K/ Pid/ 1982 tanggal 15 Desember 1983 atas nama terdakwa Drs. Raden Sonson Natalegawa.

\section{PENUTUP}

\section{A. Kesimpulan}

1. Kebijakan formulasi asas sifat melawan hukum materiel dalam hukum positif saat ini dapat dijumpai dalam KUHP (secara implisit di dalam aturan khususnya) bukan di dalam aturan umumnya, yaitu dari adanya unsur "melawan hukum" dalam perumusan delik tertentu di dalam aturan khusus KUHP(antara lain dalam Pasal 167 ayat (1), Pasal 333, Pasal 368 ayat (1), dan Pasal 406). Apabila unsur "melawan hukum" dalam rumusan delik tersebut tidak terbukti, maka terdakwa tidak dapat dipidana. Jadi asas sifat melawan hukum materiel yang 
terdapat dalam KUHP adalah asas sifat melawan hukum materiel dalam fungsinya yang negatif. Namun, meskipun terdapat dalam aturan khusus KUHP secara implisit, formulasi yang demikian merupakan suatu kelemahan karena dikhawatirkan asas tersebut akan tetap dilupakan, dinisbikan bahkan diharamkan dalam pemberlakuan/ praktek hukum pidana.

2. Penerapan asas sifat melawan hukum materiel dalam praktik hukum pidana Indonesia adalah menggunakan asas sifat melawan hukum materiel dalam fungsinya yang negatif maupun fungsinyayang positif, sedangkan asas sifat melawan hukum formil sudah tidak dianut. Dalam praktik peradilan juga banyak dijumpai beberapa putusan yang mengakui asas sifat melawan hukum materiel baik dalam fungsinya yang negatif maupun yang positif.

\section{B. Saran}

1. Dikarenakan masyarakat terus bergerak dari waktu ke waktu, yang diikuti dengan bergeraknya rasa keadilan masyarakat, maka diharapkan suatu peraturan perundangundangan dirumuskan/ disusun secara fleksibel guna mengikuti perkembangan masyarakat itu sendiri. Salah satunya adalah dengan mengakomodir hukum yang tidak tertulis dan asas sifat melawan hukum materiel baik dalam fungsi yang negatif maupun fungsinya yang positif yang dikenal dalam praktik dan ilmu hukum selama ini, sebagai sumber hukum/ dasar patut dipidananya suatu perbuatan, yang sekaligus juga sebagai dasar untuk tidak menjatuhkan pidana pada perbuatan yang tidak melawan hukum.

2. Sehubungan dengan hukum yang selalu tertinggal dari perkembangan masyarakat, diharapkan terhadap aparat penegak hukum, khususnya hakim untuk dapat meningkatkan kualitas kinerjanya guna memenuhi/ memberikan rasa keadilan bagi masyarakat.

\section{DAFTAR PUSTAKA}

\section{A. Buku-Buku}

Moeljatno, Asas-Asas Hukum Pidana (Edisi revisi), Penerbit Rineka Cipta, Jakarta, 2008.

Muladi dan Barda Nawawi Arief, Teori-teori dan Kebijakan Pidana, Penerbit PT. Alumni Bandung, 2005.

Nawawi Arief, Barda, Bunga Rampai Kebijakan Hukum Pidana Perkembangan Penyusunan Konsep KUHP Baru, Kencana, Jakarta, 2008. 
Nawawi Arief, Barda, Perkembangan Asas Hukum Pidana Indonesia, Penerbit Pustaka Magister, Semarang, 2008.

Sudarto, Hukum Pidana I, Yayasan Sudarto, Fakultas Hukum UNDIP, Semarang, 1990.

Soetandyo Wignjosoebroto, Hukum Dalam Masyarakat Perkembangan dan Masalah: Sebuah Pengantar Ke Arah Kajian Sosiologi Hukum, Bayumedia Publishing, Malang, 2008.

\section{B. Peraturan Perundang-Undangan}

Kitab Undang-undang Hukum Pidana (KUHP)

Rancangan Kitab Undang-undang Hukum Pidana Tahun 2008

Undang-Undang Dasar Negara Republik Indonesia Tahun 1945

Undang-undang Nomor 1 Drt. 1951 tentang Tindakan-Tindakan Sementara Untuk Menyelenggarakan Kesatuan Susunan, Kekuasaan dan Pengadilan-Pengadilan Sipil 